Eskişehir Osmangazi Üniversitesi Mühendislik ve Mimarlık Fakültesi Dergisi 26(2), 40-46, 2018
The Journal of Engineering and Architecture Faculty of Eskisehir Osmangazi University 26(2), 40-46, 2018

\title{
PRODUCTION AND ANALYSIS OF FUNCTIONAL SEBS NANOFIBERS BY ELECTROSPINNING
}

\author{
Esra AKKULAKㄴ, Hazal GERGEROGLU², Hamed GHORBANPOOR³ , Bedri BAKSAN ${ }^{4}$, Fatma Doğan GÜZEL ${ }^{5}$, \\ Hüseyin AVCI6*
}

${ }^{1}$ Eskişehir Osmangazi Üniversitesi, Mühendislik Mimarlık Fakültesi, Batı Meşelik Yerleşkesi, Metalurji ve Malzeme Mühendisliği Bölümü, Eskişehir, e-posta:saylan89 esra@hotmail.com, ORCID No:https://orcid.org/0000-0003-3863778X

2Eskişehir Osmangazi Üniversitesi, Mühendislik Mimarlık Fakültesi, Batı Meşelik Yerleşkesi, Nanobilim ve Nanoteknoloji Bölümü, Eskișehir, e-posta: hazal.gerger@gmail.com ORCID No:https://orcid.org/0000-0001-8369-9221

${ }^{3}$ Eskișehir Osmangazi Üniversitesi, Fen Fakültesi, Batı Meșelik Yerleșkesi, Polimer Bilimi ve Teknoloji Bölümü,

Eskişehir, e-posta: hamedeghorbanpoor@gmail.com ORCID No: https://orcid.org/0000-0002-2665-8172

${ }^{4}$ Eskişehir Osmangazi Üniversitesi, Mühendislik Mimarlık Fakültesi, Batı Meșelik Yerleşkesi, Metalurji ve Malzeme

Mühendisliği Bölümü, Eskişehir, e-posta: baksan@ogu.edu.tr, ORCID No: https://orcid.org/0000-0002-3732-5998

${ }^{5}$ Ankara Yıldırım Beyazıt Üniversitesi, Mühendislik ve Doğa Bilimleri Fakültesi, Biyomedikal Mühendisliği, Batı

Kampusu, Ankara, e-posta: fdogan@ybu.edu.tr, ORCID No: https://orcid.org/0000-0001-7200-4615

${ }^{6}$ Eskişehir Osmangazi Üniversitesi, Mühendislik Mimarlık Fakültesi, Batı Meşelik Yerleşkesi, Metalurji ve Malzeme

Mühendisliği Bölümü, Eskişehir, e-posta: havci@ogu.edu.tr , ORCID No: https://orcid.org/0000-0002-2475-1963

DOI : http://dx.doi.org/10.31796/ogummf.329811

Makale Geliş: 20.07.2017

Makale Kabul: 20.12.2017

Araştırma Makalesi

\section{Fonksiyonel SEBS Nanofiberlerinin Elektro Çekim İle Üretim Ve Analizi}

\section{Öz}

Termoplastik elastomerler (TPE), hızl prototipleme sayesinde, araștırmacılara yumuşak ve jöle benzeri yapılardan sert ve rijit malzemelere kadar geniş bir tasarım imkânı sağlayabilme kapasitesine sahiptir. Bu bağlamda, poli(stiren-b-(etilen-kobütilen)-b-stiren) (SEBS) triblok kopolimerleri birçok farklı olumlu özelliklere sahiptir ve farklı uygulamalar için cihazların tasarımı ve gereksinimleri düşünüldügünde çok umut vericidir. SEBS triblock kopolimerinin termoplastik ve elastomerik özelliklerinin kombinasyonu büyük ölçekli malzemelerin üretiminde potansiyel malzemeden biridir. Bu çalıșmada, elektro çekimin yararlarından faydalınarak SEBS triblock kopolimerden ortalama çapları $286 \pm 93 \mathrm{~nm}$ olan yüksek elastik ve fonksiyonel nanofiberler bildiğimiz kadarlyla literatüre göre ilk defa üretilmiştir. Elde edilen bu fonksiyonel elektrospan nanofiberlerinin yakın gelecekte tıbbi ve su arıtımı uygulamalarında yaygın olarak kullanılacağına inanıyoruz.

Anahtar Kelimeler : Poli (stiren-b- (etilen-ko-butilen) - $b$ stiren), elektro çekim, nanofiber, tıbbi, filtrasyon.
Article Received: 20.07.2017

Article Accepted: 20.12.2017

Research Article

\section{Production and Analysis of Functional SEBS Nanofibers by Electrospinning}

\begin{abstract}
Thermoplastic elastomers (TPE) offers wide design opportunities because of its rapid prototyping that provides researchers with the acquisition of many different material properties from softness and jelly-like properties to hardness and rigidity. In this regard, poly(styrene-b-(ethylene-cobutylene)-b-styrene) (SEBS) triblock copolymer has many positive aspects and is very promising when the design and requirements of devices for different applications are considered. The combination of thermoplastic and elastomeric properties of SEBS triblock copolymer makes it one of the potential materials in the production of large-scale materials. In this study, highly elastic and functional nanofibers from SEBS triblock copolymer with the diameters of $286 \pm 93 \mathrm{~nm}$ were produced successfully by electrospinning for the first time, to the best of our knowledge. We believe that SEBS-based functional electrospun nanofibers will find widespread applications in medicine and water purification in the near future.
\end{abstract}

Keywords : poly (styrene-b- (ethylene-co-butylene)- $b$ styrene), electrospinning, nanofibers, medical, filtration.

\footnotetext{
* Corresponding author: havci@ogu.edu.tr Tel: 0.222.239 3750 / 3688
} 


\section{Introduction}

Thermoplastic elastomers have excellent processing properties at high temperatures and demonstrate physical properties of elastomers at the working temperature. TPEs can be classified as a multi-phase material comprising rigid thermoplastic and soft rubbery phase. At the working temperature, the rigid thermoplastic phase coalesces to form small areas that function as physical cross-links between the soft blocks. Over the glass transition temperature $(\mathrm{Tg})$ or melting temperature $(\mathrm{Tm})$ of the thermoplastic phase, the physical cross-links disappear and the material becomes melt-processable (Ismail et al., 2016). TPEs can be produced by blending different compounds and this allows the adjustment of several processing properties and improvements in the material specifications, performance and functionality while also reducing the cost.

Since their introduction to the market, many different TPEs have been produced. The major share of the TPE market is composed of elastomers with basic structures of polystyrene (PS) block copolymers and poly(styrenebutadiene-styrene) (SBS) or poly(styrene-isoprene styrene) (SIS). In SBS and SIS, the rubbery phase is more susceptible to degradation than that of PS. This is due to the presence of reactive double bonds present in the rubbery phase and low glassy-rubbery transition temperatures. To improve the degradation resistance, the 2nd generation of PS-elastomer block copolymers with hydrogenated midblock using SEBS copolymers were released to the market after 10 years of the commercial introduction of SBS (White et al., 2011). SEBS triblock copolymers are composed of physically cross-linked soft polybutadiene and hard polystyrene segments. The soft parts of the SEBS are responsible for elastomeric properties and high resistance to thermal degradation. The hard parts are responsible for both thermoplastic performance (crystal formation) and mechanical strength (Latko et al., 2017). It is widely used due to the coexistence of soft elastomer and hard polystyrene phases. The styrenic block copolymer has remarkable mechanical properties such as ease of deformation at ambient temperature, excellent elongation and elasticity before the breaking. SEBS is also an easily processable and blendable polymer, hence finds widespread use in different applications, including coatings, adhesives, sealants and impact plastics in engineering applications (Li et al., 2017). The molecular structure of SEBS is shown in Figure 1 (Zhou et al., 2010).

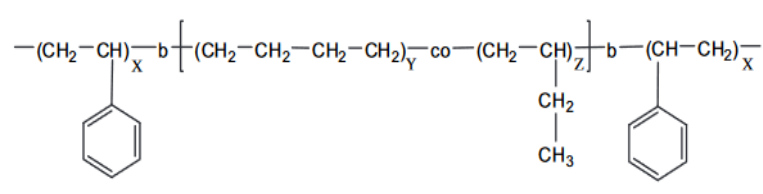

\section{Figure 1. Molecular structure of SEBS, $\mathrm{X}$ is hard, $\mathrm{Y}+$ $\mathrm{Z}$ are soft blocks.}

SEBS copolymer is also widely used in medical applications. For example, Shi et al. investigated the release of ascorbic acid and lecithin from core-shell nanofibers in contact with blood to reduce long-term hemolysis of erythrocytes and used SEBS copolymer in their experiments. As a result, mechanical and oxidative damage to erythrocyte membrane was reduced (Shi et al., 2015). In another study, glycidyl methacrylatehyaluronic acid was prepared and covalently-grafted onto the SEBS surface by light-initiated polymerization to obtain biocompatible matrices. By doing so, biological performance of the modified base, including platelet adhesion and cell responses, was investigated (Li et al., 2013).

Shi et al. obtained D- $\alpha$-tocopheryl polyethylene glycol succinate / polyethylene oxide (TPGS / PEO) core-shell nanofibers on the SEBS surface grafted with polyethylene glycol (PEG) chains by coaxial electrospinning technique. Here in this study TPGS released from nanofibers acts as an antioxidant to protect erythrocytes from oxidative damage and reduces mechanical damage to erythrocytes in PEGgrafted layers. The grafted PEG chains provide a hydration layer on the surface of the SEBS to reduce the collision between the erythrocytes and the SEBS surface and prevents sticking of the erythrocytes, resulting in reduced mechanical damage to the erythrocyte membrane. This study proves to be useful for the production of long-term anti-hemolytic in vitro biomaterials-a new pathway for the development of non-plasticized polymers for erythrocyte protection (Shi et al., 2015).

There are handful number of research carried out with SEBS-based polymers in the field of medicine and there is almost no study that showed the production of the nano-sized fibers of SEBS triblock copolymers by using electrospinning or any other technique. It is possible to obtain nano-sized fibers since the first half of the $20^{\text {th }}$ century with various morphology, properties and compositions by applying the electrospinning technique (Avci et al., 2013; Calisir et al., 2016; Gergeroglu et al., 2017). Previously Rungswang et al. (2013) and Kurusu et al. (2015) have showed how to produce fibers at micron level by electrospinning method by using SEBS polymer. Here, it is the first time, we report the production of nano-sized fibers of SEBS triblock 
copolymers by using electrospinning technique. Morphology and mechanical analysis were also performed to assess its performance and results were compared with thermoplastic polyurethane (TPU) based nanofibers.

We believe that the produced SEBS-based nanofibers are versatile and will soon find effective usage in medical and water purification applications.

\section{Materials and Methods}

\subsection{Material and Electrospinning Process}

SEBS triblock copolymer was supplied as granules from Kraton Inc. with the trademark of G1652 E $\left(\mathrm{M}_{\mathrm{w}} \sim 82,000\right.$ $\mathrm{g} \mathrm{mol}^{-1}$ ) and has a styrene content of $30 \%$ by weight. Dimethylformamide (DMF) and toluene were used as the solvents of TPU and SEBS, purchased from Sigma Aldrich. TPU (Elastollan C95A) was also obtained from BASF. The optimum electrospinning solution was determined by varying the concentration from $7 \mathrm{wt} \%$ to $24 \mathrm{wt} \%$.

\subsection{Microwave Treatment}

A microwave oven at a low power level of about 250watt power with the frequency of $2.45 \mathrm{GHz}$ was used for the SEBS triblok copolymer solution to completely dissolves, leaving no remaining polymer.

\subsection{Morphology Analysis}

Scanning Electron Microscope (SEM) characterization of the nanofibers was performed by using the JEOL JSM 5600 instrument. All samples were first coated with 5 $\mathrm{nm}$ of $\mathrm{Au}$ and Pd under an inert gas atmosphere for SEM characterization. The average fiber diameters of the produced nanofibers were calculated using the Image J program and the measurements were taken from at least 50 different sites.

\subsection{Mechanical Analysis}

Mechanical analysis was carried out using Shimadzu AGS-X instrument. In the analysis, a force applied to the specimens with the dimension of $20 \mathrm{~mm} \times 10 \mathrm{~mm}$ at a crosshead speed of $20 \mathrm{~mm} / \mathrm{min}$ according to ASTM standard of D882 and D535 (Kumar and Vasita, 2017). As a result of the test, modulus of elasticity (E), tensile strength and elongation at break were investigated.

\section{Result and Discussion}

\subsection{SEM Characterization and Optimization of SEBS Nanofibers}

It is well known that the changes in solution concentration, viscosity and surface tension are important parameters affecting the fiber formation. Fibers with beaded structure can be formed due to the low surface tension of the solution with low concentration while the formation of fiber due to higher viscosity can be seen with the solution of the higher concentration (Subbiah et al., 2005). In the first trial, toluene solvent mixtures containing $7 \mathrm{wt} \%$ and $14 \mathrm{wt} \%$ SEBS were prepared, and these two solutions were stirred by a magnetic stirrer at $25^{\circ} \mathrm{C}$ for 8 hours until colorless solutions were obtained. Later, attempts were made to produce nanofibers from electrospinning solutions transferred into the syringe, but no fiber formation was observed with either solution as seen in Figure 2. During the electrospinning process, the charges on the surface of the jet formed at the tip of the syringe repulse each other. For this reason, extensions occur on the jet. The conductivity of the solution can be increased to carry more load on the solution. If the electrospinning solution does not exhibit sufficient stress, the bead structure can be observed on the collector. To overcome this problem, salt can be added to the electrospinning solution (Zong et al., 2002). Hence, $4 \mathrm{wt} \% \mathrm{NaCl}$ was added to toluene solvent mixtures containing SEBS concentration of $7 \mathrm{wt} \%$ and $14 \mathrm{wt} \%$ and electrospinning process was performed again. Although the fiber formation was observed, continuity was not achieved and the solution dripped to the substrate at regular intervals. The reason can be the molecular weight or the concentration of the polymers affects the solution viscosity. It is reported that when the viscosity of the solution used is low, the solution drops by the force of gravity during the process and drops from the needle point, thus preventing the production (Deitzel et al., 2001). For this reason, further experiments were carried out with the higher concentration of the polymer in the solution.

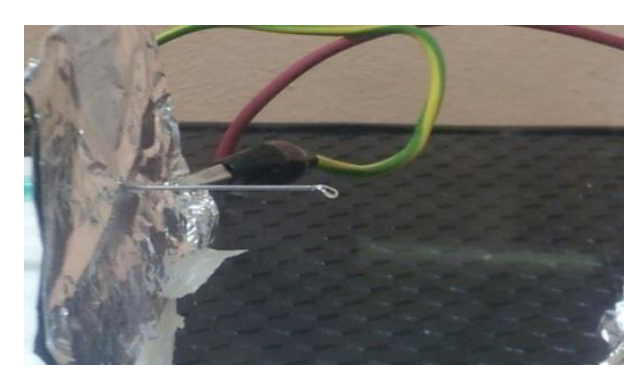

Figure 2. An image of SEBS-toluene electrospinning solution solidified at the syringe tip during the process. 
In addition, during the electrospinning process, the solvent in the solution must evaporate rapidly. In course of the jet thinning, phase separation is formed. Some of the most important parameters for the electrospinning process include the evaporation rate and the vapor pressure of the solvent in the solution. It has been reported that the average fiber diameter of the nanofibers obtained from the solutions prepared using higher concentration of DMF decreases. It is also known that more uniform and dense fiber can be obtained by using highly volatile solutions (Subbiah et al., 2005; Ramarkrisha et al., 2005).

On the other hand, DMF-Toluene $(1: 1 \mathrm{v} / \mathrm{v})$ solvent mixture containing $15 \mathrm{wt} \%$ SEBS concentration was
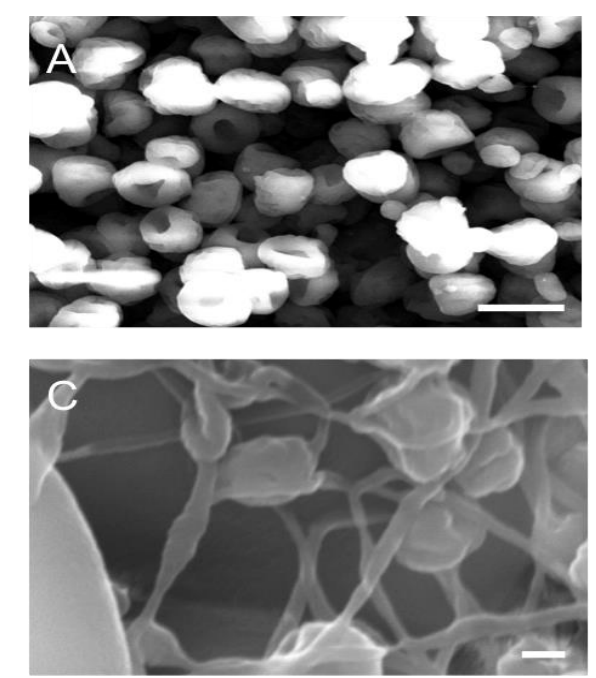

stirred at $500 \mathrm{rpm}$ at $50{ }^{\circ} \mathrm{C}$ but turbidity was observed. Therefore, a mixture of DMF-toluene $(3: 7 \mathrm{v} / \mathrm{v})$ containing $15 \mathrm{wt} \%$ SEBS was prepared and stirred until completely dissolved at $500 \mathrm{rpm}$ at $50{ }^{\circ} \mathrm{C}$ temperature in which a colorless electrospinning solution was obtained. The electrospinning of the prepared solution was carried out at room temperature under a voltage of $15 \mathrm{kV}$ and a flow rate of $1 \mathrm{~mL} / \mathrm{hr}$ at syringe tip-collector distance of $10 \mathrm{~cm}$. As seen in Figure $3 \mathrm{~A}$, the beaded structures were observed. It is reported in the literature that if the solution viscosity is low, bead-like structures can be observed and the liquid jet breaks during the production. As viscosity increases, the beaded structures become ellipse-like structure from spherical (Deitzel et al., 2001).
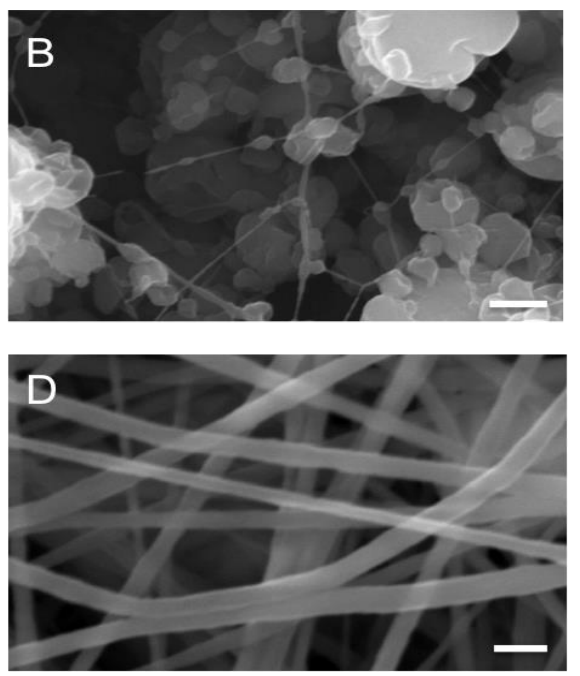

Figure 3. SEM images of the fiber morphologies produced under different conditions by using DMF-toluene (3:7 v/v) solution. A. 15 wt\% SEBS (Scale bar is $10 \mu \mathrm{m}$ ). B. 18 wt\% SEBS (Scale bar is $2 \mu \mathrm{m}$ ). C. 21 wt $\%$ SEBS (Scale bar is $1 \mu \mathrm{m}$ ). D. $24 \mathrm{wt} \%$ SEBS (Scale bar is $1 \mu \mathrm{m}$ ).

DMF-Toluene $(3: 7 \mathrm{v} / \mathrm{v})$ solution containing $18 \mathrm{wt} \%$ SEBS concentration was then prepared and mixed until completely dissolved at $400 \mathrm{rpm}$ at $50{ }^{\circ} \mathrm{C}$ to obtain a colorless solution. The electrospinning of the prepared solution was carried out at a temperature of $18{ }^{\circ} \mathrm{C}$ with a humidity of $39.6 \%$ at a distance of $10 \mathrm{~cm}$ under a voltage of $17 \mathrm{kV}$ and a flow rate of $12 \mu \mathrm{L} / \mathrm{min}$. It is clearly seen that although there is a high bead density, the fiber structure started to form as follow (Figure 3B). This is a strong indication that the increase in solution viscosity leads to the formation of uniform fiber structure under optimized conditions. Therefore, the polymer concentration was further increased to $21 \mathrm{wt} \%$. After many trials, the electrospinning of the prepared solution was fixed under about $17^{\circ} \mathrm{C}$ with applying the voltage of $17 \mathrm{kV}$ and at a flow rate of $10 \mathrm{~mL} / \mathrm{hr}$ with a distance of $10 \mathrm{~cm}$ under $47 \%$ humidity. As can be seen in Figure 3C, further improvement of the fiber structure was observed.
In order to fabricate the electrospun fibers with desired morphologies and smaller diameters, the concentration of $24 \mathrm{wt} \%$ SEBS was prepared. Uniform and nano-sized fiber formation was obtained under the electrospinning conditions of $10 \mathrm{~cm}$ distance at a flow rate of $10 \mathrm{~mL} / \mathrm{hr}$ at $17{ }^{\circ} \mathrm{C}, 18 \mathrm{kV}$ applied voltage under $47 \%$ humidity. As seen in Figure 3D, improved fiber structure and morphology were obtained uniformly with the average fiber diameter of about $357 \mathrm{n}$

Besides the influence of solution concentration on the fiber structure, the effect of other parameters such as humidity was also investigated. It is stated in the literature that if the relative humidity of the environment is greater than $60 \%$, it can prevent the formation of nanofibers (Subbiah et al., 2005). In addition, as the relative humidity increases, the fiber diameter also increases, which is due to the electrical charging on the surface of the polymer solution 
(Kozanoğlu et al., 2006). Therefore, in our experiment, further re-optimization steps were necessarily carried out. In order to improve on the nanofiber structures, 24 wt\% SEBS triblock copolymer solution was microwaved for 105 seconds in total while power level was kept at about 250 -watt with the frequency of $2.45 \mathrm{GHz}$ for 20 25 - 40 - 20 seconds. It was then stirred at $25^{\circ} \mathrm{C}$ in a magnetic stirrer until a colorless level was achieved at $600 \mathrm{rpm}$. The dissolved solution was successfully transformed to the nanofibers at an average diameter of
$286 \pm 93 \mathrm{~nm}$ upon the application of $18 \mathrm{kV}$ voltage with a flow rate of $2 \mathrm{~mL} / \mathrm{hr}$ at a distance of $10 \mathrm{~cm}$ (Figure 4A). As reported previously, the dissolution of some natural and synthetic polymers can be facilitated by microwave irradiation (Swatloski et al., 2013). The effect of microwave radiation on the polar solvent of DMF can improve oxygen mobility resulting much faster dissolving process than the conventional methods (Cadafalch Gazquez et al., 2017).
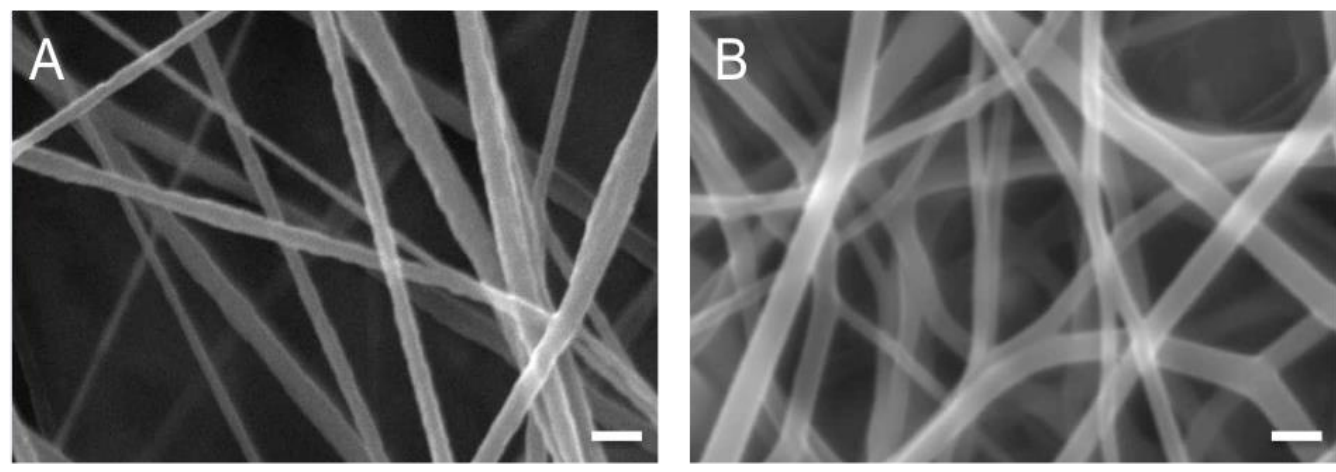

Figure 4. SEM images of the fiber morphologies produced using SEBS (upon microwave treatment) and TPU polymers. A. Electrospun nanofibers by using DMF-Toluene (3:7 v/v) containing $24 \mathrm{wt} \%$ SEBS after the microwave oven treatment. B. Electrospun nanofibers by using DMF containing 18 wt\% TPU. (Scale bar is 1 $\mu \mathrm{m})$.

SEBS nanofibers were also compared with TPU nanofibers to demonstrate the relative differences. Uniform TPU nanofibers were obtained with an average diameter of about $314 \mathrm{~nm}$ (Figure 4B). Size analysis was performed using at least 50 different nanofibers from SEM images. The process parameters were fixed at the solution conditions containing $18 \mathrm{wt} \% \mathrm{TPU}$, a flow rate of $0.2 \mathrm{~mL} / \mathrm{hr}$ at a distance of $20 \mathrm{~cm}$ under an applied voltage of $24 \mathrm{kV}$.

\subsection{Mechanical Analysis}

The mechanical properties of the materials used in different fields such as medicine and engineering must meet the requirements for the specific application area. For example, in some cases the elongation at break is important while sometimes the strength is at the foreground. Thus, the mechanical properties of SEBS nanofibers were investigated and compared with TPU nanofibers. Although the tensile stress for SEBS nanofibers of about $0.62 \mathrm{MPa}$ is lower when we compared with TPU of about $3.66 \mathrm{MPa}$, a very high elongation at break of about $380 \%$ for SEBS was achieved against TPU of $108 \%$ (Figure 5). Kurusu et al. demonstrated similar performance for micron-sized SEBS electrospun mats with $0.88 \mathrm{MPa}$ for the tensile stress and $>300 \%$ for the elongation at break. This result increases the potential for use in a certain specific medical and filtration, especially where high elasticity is needed. Furthermore, in the SEBS triblock copolymer, it is possible to obtain different mechanical properties by varying the percentage of its block parts. These preliminary mechanical properties show promising results and open avenues for possibility of replacing TPU in different applications in the near future. Figure 5A and 5B display stress-strain graphs for SEBS and TPU nanofibers, respectively. 


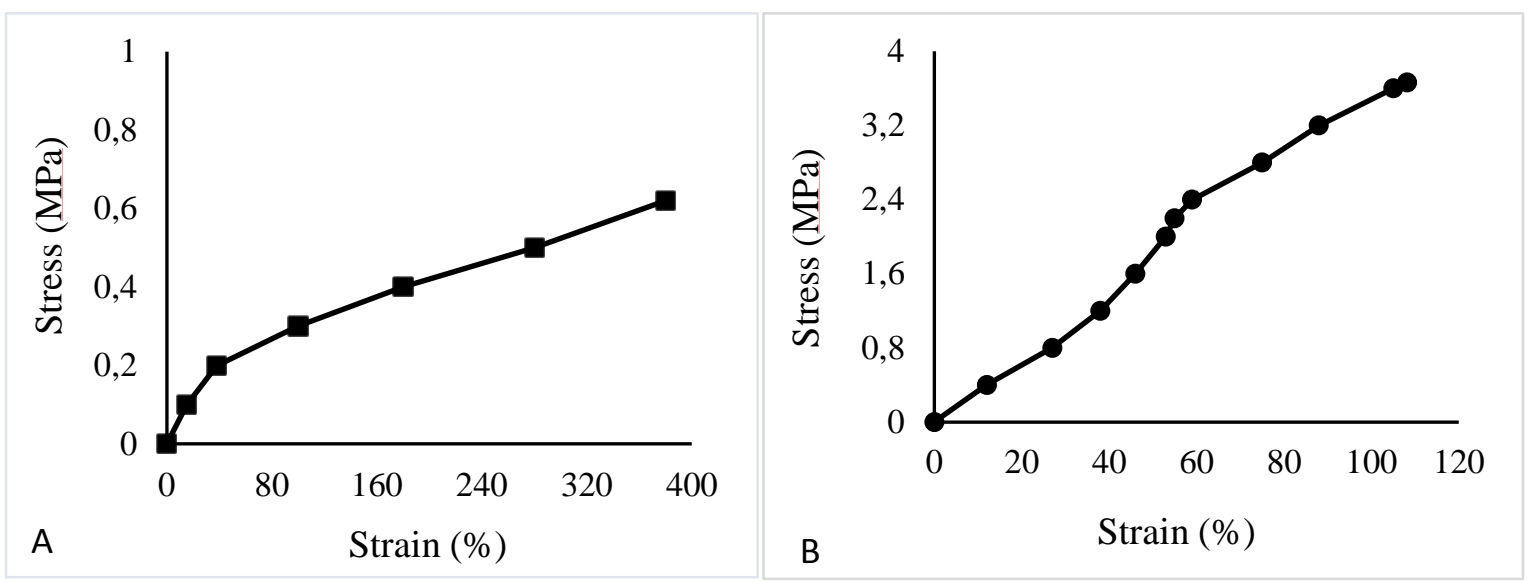

Figure 5. A. Stress - strain graphs for SEBS, B. TPU nanofibers.

\section{Conclusion}

In this study, the production of nanofibers from the SEBS triblock copolymer has been successfully accomplished for the first time. SEBS solutions were prepared at different concentrations and the most suitable solution was determined as DMF:Toluene (3:7 $(\mathrm{v} / \mathrm{v}))$ containing $24 \mathrm{wt} \%$ SEBS. At this specific concentration, nanofibers of about $356 \mathrm{~nm}$ in diameter were obtained. In addition, smaller sizes of nanofibers in diameter $(286 \mathrm{~nm})$ were obtained by increasing the relative humidity and microwave treatment of the solution.

When the mechanical analysis results are examined, it was found that the elongation at break of SEBS triblock copolymer is much higher than TPU polymer. At the same time, the SEBS nanofiber strength is sufficient enough for use, for example, in medical and filtration fields. It is also clearly understood that the addition of suitable additives to SEBS triblock copolymer has a strong potential to produce wound-dressing materials. Therefore, water filtration and antibacterial tests of SEBS nanofibers with the additives are still continuing. With further investigations, we hope to develop a new generation nanofibers for different applications; especially for medical and water filtration technologies.

\section{Acknowledgments}

The authors gratefully acknowledge the ESOGU Scientific Research Fund (ESOGU-BAP grant number 2015-799) for the financial support of this research.

\section{Conflict of Interest}

No conflict of interest was declared by the authors.

\section{References}

Avci, H., Monticello, R., and Kotek, R. (2013). Preparation of Antibacterial PVA And PEO Nanofibers Containing Lawsonia Inermis (Henna) Leaf Extracts. Journal of Biomaterials Science, Polymer Edition, 24(16), 18151830.

Cadafalch Gazquez, G., Smulders, V., Veldhuis, S. A., Wieringa, P., Moroni, L., Boukamp, B. A., and Ten Elshof, J. E. (2017). Influence of Solution Properties and Process Parameters on The Formation and Morphology of YSZ And NIO Ceramic Nanofibers by Electrospinning. Nanomaterials, 7(1), 1-15.

Calisir, M. D., Erol, M., Kilic, A., and Avci, H. (2016). Photophysical Properties of Phosphorescent Elastomeric Composite Nanofibers. Dyes and Pigments, 125, 95-99.

Deitzel, J. M., Kleinmeyer, J., Harris, D. E. A., and Tan, N. B. (2001). The Effect of Processing Variables on The Morphology of Electrospun Nanofibers And Textiles. Polymer, 42(1), 261-272.

Gergeroglu, H., and Avcl, H. (2017). Functional Composite Nanofibers Derived from Natural Extract of Satureja Hortensis. Anadolu Üniversitesi Bilim ve Teknoloji Dergisi A-Uygulamalı Bilimler ve Mühendislik, 908-918.

Ismail, S. M. R. S., Chatterjee, T., and Naskar, K. (2017). Superior Heat-Resistant and Oil-Resistant Blends Based on Dynamically Vulcanized Hydrogenated Acrylonitrile Butadiene Rubber and Polyamide 12. Polymers for Advanced Technologies, 28(6), 665-678.

Kozanoğlu, G. S. (2015). Elektrospinning Yöntemiyle Nanolif Üretim Teknolojisi, Istanbul Technical 
University (Doctoral dissertation, Institute of Science and Technology).

Kumar, P. and Vasita, R. (2017) Understanding the Relation Between Structural and Mechanical Properties of Electrospun Fiber Mesh Through Uniaxial Tensile Testing. Journal of Applied Polymer Science 134 (26), 1-11.

Kurusu, R. S., and Demarquette, N. R. (2015). Blending and Morphology Control to Turn Hydrophobic SEBS Electrospun Mats Superhydrophilic. Langmuir, 31(19), 5495-5503.

Latko, P., Bielecki, M., Kozera, R., and Boczkowska, A. (2017). Relationship Between Processing and Electrical Properties in SEBS/CNT Nanocomposites. Journal of Elastomers and Plastics, 49(4), 356-367.

Li, X., Luan, S., Shi, H., Yang, H., Song, L., Jin, J., ... and Stagnaro, P. (2013). Improved Biocompatibility of Poly (Styrene-B-(Ethylene-Co-Butylene)-B-Styrene) Elastomer by A Surface Graft Polymerization of Hyaluronic Acid. Colloids and Surfaces B: Biointerfaces, 102, 210-217.

Li, X., Tang, S., Zhou, X., Gu, S., Huang, K., Xu, J., ... and Li, Y. (2017). Synergistic Effect of Amino Silane Functional Montmorillonite on Intumescent FlameRetarded SEBS and Its Mechanism. Journal of Applied Polymer Science, 134(24). 1-11

Ramakrishna, S., Fujihara, K., Teo, W. E., Lim, T. C., and $\mathrm{Ma}, \mathrm{Z}$ (2005). An Introduction to Electrospinning and Nanofibers. Singapura: World Scientific Publishing Company.

Rungswang, W., Kotaki, M., Shimojima, T., Kimura, G., Sakurai, S., and Chirachanchai, S. (2011). Existence of Microdomain Orientation in Thermoplastic Elastomer Through a Case Study of SEBS Electrospun Fibers. Polymer, 52(3), 844-853.

Shi, Q., Fan, Q., Ye, W., Hou, J., Wong, S. C., Xu, X., and Yin, J. (2015). Binary Release of Ascorbic Acid and Lecithin from Core-Shell Nanofibers on BloodContacting Surface for Reducing Long-Term Hemolysis of Erythrocyte. Colloids and Surfaces B: Biointerfaces, 125, 28-33.

Shi, Q., Xu, X., Fan, Q., Hou, J., Ye, W., and Yin, J. (2015). Construction of D-A-Tocopheryl Polyethylene Glycol Succinate/PEO Core-Shell Nanofibers an A BloodContacting Surface to Reduce The Hemolysis of Preserved Erythrocytes. Journal of Materials Chemistry B, 3(10), 2119-2126.

Subbiah, T., Bhat, G. S., Tock, R. W., Parameswaran, S., and Ramkumar, S. S. (2005). Electrospinning of Nanofibers. Journal of Applied Polymer Science, 96(2), 557-569.
Swatloski, R. P., Barber, P. S., Opichka, T., Bonner, J. R., Gurau, G., Griggs, C. S., and Rogers, R. D. (2013). U.S. Patent Application No. 13/949,501.

White, C. C., Tan, K. T., Hunston, D. L., Nguyen, T., Benatti, D. J., Stanley, D., and Chin, J. W. (2011). Laboratory Accelerated and Natural Weathering of StyreneEthylene-Butylene-Styrene (SEBS) Block Copolymer. Polymer Degradation and Stability, 96(6), 1104-1110.

Zhou, T., Wu, Z., Li, Y., Luo, J., Chen, Z., Xia, J. and Zhang, A. (2010). Order-order, Lattice Disordering, and Order-Disorder Transition in SEBS Studied by TwoDimensional Correlation Infrared Spectroscopy. Polymer, 51(18), 4249-4258.

Zong, X., Kim, K., Fang, D., Ran, S., Hsiao, B. S., and Chu, B. (2002). Structure and Process Relationship of Electrospun Bioabsorbable Nanofiber Membranes. Polymer, 43(16), 4403-4412. 